(2) Tested $27^{\text {th }}$ January 1906 at 10 p.m.-

27 th, 6 p.m. $102^{\circ} ; 28$ th, 7 a.m. $102^{\circ}$, IO a.m. IO2 $3^{\circ}$, I p.m. $1024^{\circ}$.

(3) Tested 26 th April I906 at Io p.m.-

26 th, 7 a.m. $102^{\circ}, 4$ p.m. $1026^{\circ} ; 27$ th, 7 a.m. $1024^{\circ}$; IO a.m. IOI.8 , p.m. $102^{\circ}$.

(4) Tested 3rd September 1906 at 10 p.m.-

$3 \mathrm{rd}, 7$ a.m. IOI $4^{\circ}, 4$ p.m. IOI $2^{\circ} ; 4^{\text {th, }} 7$ a.m. IO $2^{\circ}, 10$ a.m. IO $2^{\circ}$, I p.m. IOI $^{\circ} 4^{\circ}$.

(5) Tested Sth July I907 at 8 p.m.-

8 th, 8 a.m. IOI $7^{\circ}$, 5 p.m. $102 \cdot 6^{\circ}$; 9 th, 8 a.m. $104 \cdot 6^{\circ}$, I I a.m. $105^{\circ} 8^{\circ}$, 2 p.m. $105^{\circ}$.

The bull was destroyed on 29th July I907, and I was unable to ind any definite lesions (tuberculous) upon post-mortem examination. The cow was destroyed on 20th August 1907, and the carcase presented extensive tuberculous lesions, many of which were calcareous. The tuberculin used was applied to other animals during the same periods, and those which reacted were in each case found to be tuberculous upon post-mortem examination. The tests were carried out under ideal conditions with regard to stabling, attendance, etc.

\title{
REMARKABLE CASE OF POISONING OF ANIMALS WITH NATURALLY EXHALED GAS IN THE KE- DONG VALLEY, EAST AFRICA.
}

\author{
By R. J. STORdy, M.R.C.V.S., Chief Veterinary Surgeon, \\ British East Africa Protectorate.
}

TowARDs the end of August last it was reported that buffalo were dying in the Kedong Valley, and I instructed Captain Neave to proceed there to investigate the matter. Proceeding from the foot of the Escarpment, parallel to the old rope inclines, and about two hours' walk from Escarpment Station, he discovered a hole about 2 feet wide and 4 to 5 feet high, situated under a bank on one side of a gully, in which there was a luxuriant growth of grass. Near this spot were lying the carcases of six buffalo, too far decomposed for examination, and strewn around the hole were a great number of bones, among which could be seen the skulls of several other buffalo (see fig., p. 76 ).

The native guides gave a curious account of the place, saying that a "sheitan," or devil, lived in the hole, that when he breathed his breath killed everything around, and that it was from this that the buffalo had died. They appeared to be much afraid of going anywhere near it. Captain Neave sent back to Escarpment Station for any animals that could be obtained, in order to test this statement, but only succeeded in getting two fowls. These he placed on the ground, with legs tied, a few feet from the hole, and in a few seconds the one nearest the hole was dead, and the other, after fluttering about and crowing for about a minute, was also overcome and apparently dead. On carrying them back to camp the second fowl showed signs of life, and, after inhaling ammonia fumes and being sprinkled with water, finally recovered.

The following morning a settler travelling past the camp was 
informed of the place, and, being incredulous, put his head in the hole for a few moments, by which he succeeded in giving himself a severe headache and an attack of vomiting.

It was not until the I 8 th November that I had the opportunity of visiting the hole in company with Captain Neave. I took with me five pariah dogs, two old cows, twelve sheep and goats, and several fowls. We reached our camp, a short distance from the hole, at 9.30 A.M., but the native guides told us it was useless to experiment with the animals at that time, as the noxious vapours were not then emanating. We, however, placed a dog in the hole, to which the natives give the name $\mathrm{Kia}$, with no result.

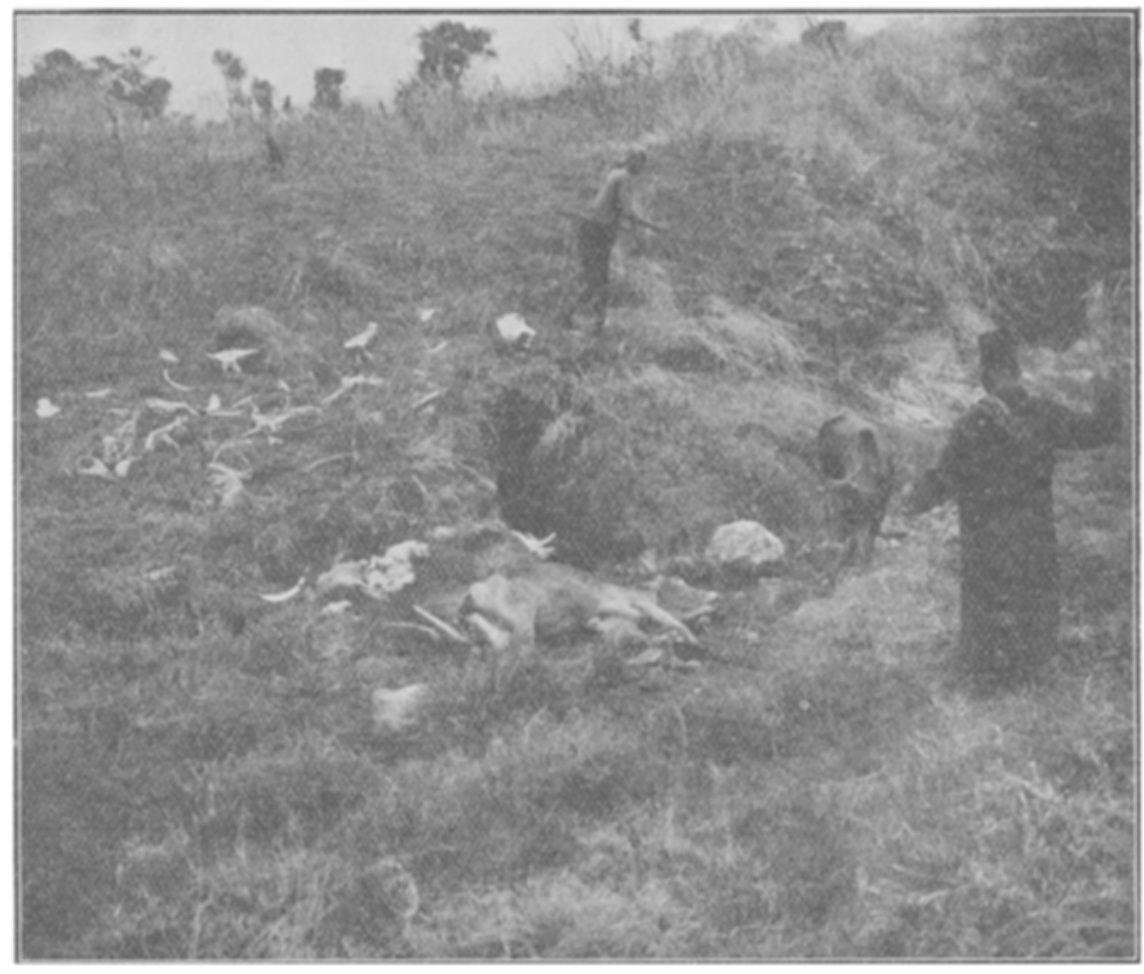

Another trial was made at 3.30 P.M., when, on placing a sheep with its nose towards the hole and close to it, it immediately began to heave violently. In a few seconds it was on its back, with its legs in the air and bleating, and in a few seconds more life was extinct.

Seven more sheep and goats were tried, at varying distances from the hole, with the same effect. The dogs were also tried with practically the same results. Two sheep were placed for a few seconds at the hole, and when they had collapsed were drawn away. from it and resuscitated, but laboured oral breathing was continued from one-half to one hour afterwards. The two cows died in a similar manner in about half a minute. All the animals gave out their peculiar cry before death, which reminded one of death from prussic acid poisoning. 
The gas was then tested with lighted cotton-wool which had been dipped in methylated spirit, and the flame was immediately extinguished on being placed in the vicinity of the hole. For some distance, 20 to 30 feet from the fissure, the gas was found lying upon the surface of the ground to a height of about 6 inches, and this had increased to a height of about i 8 inches by 5.30 P.M. The ground was distinctly hot, and the fumes on inhalation were extremely pungent and acrid. Samples of the gas were collected in bottles for analysis in Nairobi.

Several post-mortem examinations were made upon the animals destroyed, but no particular lesions were found, except that the blood was somewhat dark in colour and coagulated tardily, and the heart in all cases was in diastole.

On examining the gas in Nairobi it was found that most of it had escaped. This necessitated another visit to the hole, when further samples were obtained, and its effect upon animals re-tested. It was found on this occasion that after 6 P.M. no emission of gas took place, and one could insert one's head into the hole, which is a long tortuous rift going at an angle to apparently a considerable depth. It was re-tested early in the morning, when it was again found quiescent.

On testing the gas at the laboratory it was found to be hydrochloric acid gas. This gas is known to emanate from volcanic strata, and when one considers that it is poisonous to animal life even when diluted with 25,000 parts of air, one can readily understand the quickness of death, as recorded above.

It is of interest to note that the gas is of such a specific gravity that a dog can stand with it reaching to his elbows without being in the slightest degree inconvenienced, but the moment he lies down it means death.

The place is now fenced in, and a notice board erected warning the public of the danger. The place is attractive to animals by reason of the luxuriant crop of grass near by, which is somewhat in contrast to the surrounding arid country, and also on account of a salt deposit in the vicinity. To East Africans the place is now known as the "Devil's Breath."

\section{BLACKQUARTER IN A SIX-YEAR-OLD COW,}

$$
\text { By A. N. Foster, M.R.C.V.S., Sheffield. }
$$

ON I2th February of this year I was requested by $\mathrm{Mr}$ Elcock, the meat inspector, to examine a carcase of beef which he had seized as unfit for human food. I was informed that the animal had calved a week previously, and, owing to subsequent illness, had been slaughtered. On I Ith February it had been sent into the Sheffield Shambles and subjected to inspection.

I found that the whole of the muscular tissue of the right fore quarter-i.e., shoulder and neck, was dark and emphysematous, and from the characteristically sour odour which I obtained by cutting into the muscles at various places, and from their appearance, I considered there was very little doubt that the animal had been affected 